\title{
Health Implications of Sexual Violence Among Survivors in Selected Health Facilities in Kenya: Are There Gender Disparities?
}

\author{
Osero S. O. Justus ${ }^{1} \quad$ Margaret N. Keraka ${ }^{2}$ Syprine A. Otieno ${ }^{3}$ \\ 1.Department of Community Health and Epidemiology, School of Public Health and Applied Human Sciences, \\ Kenyatta University, P.O. Box 43844, 00100 Nairobi, Kenya \\ 2.Department of Population, Reproductive Health \& Community Resource Management, School of Public \\ Health and Applied Human Sciences, Kenyatta University, P.O. Box 43844, 00100 Nairobi, Kenya \\ 3.Department of Zoological Sciences, School of Pure and Applied Sciences, Kenyatta University, \\ P.O. Box 43844, 00100 Nairobi, Kenya
}

\begin{abstract}
Sexual based violence (SBV) is a serious public health problem with profound impact on physical, social and mental health, both immediately and many years after the assault. The global statistics on sexual assault against women indicates that, at least one in every three (34\%) has been beaten and/or coerced into sex. A World Health Organisation (WHO) multi-country study reports that between $16 \%$ and $59 \%$ women from Africa had ever experienced sexual violence. In Kenya, about $24 \%$ of women have been raped at least once. Nairobi women Hospital alone receives an average of 230 survivors per month, with approximately $45 \%$ being children, $49 \%$ women and $6 \%$ men respectively. The main aim of this study was to investigate the gender disparities in health implications of SBV among survivors in three health facilities in Kenya. This was a cross-sectional study involving $236(84.3 \%)$ female and $44(15.7 \%)$ male survivors were enrolled in the study. The study established that sexual based violence resulted into health consequences (76.8\%) including psychological trauma 143(51\%), physical injuries 75(27\%), STIs 38(14\%), gynaecological disorders 35(12\%), Human Immunodeficiency Virus (HIV) $32(11 \%)$, gastrointestinal disorders $21(7 \%)$ and unwanted pregnancies $17(6 \%)$. The results showed that females and males who developed health complications were not significantly different $\left(\chi^{2}=0.223 ; \mathrm{df}=1 ; \mathrm{p}=0.637\right)$. Males were more likely to suffer from psychological trauma, physical injuries and gastrointestinal injuries compared to females $(\mathrm{OR}=1.2, \mathrm{CI}=0.6-2.2 ; \mathrm{OR}=0.2, \mathrm{CI}=0.1-5.0$; and $\mathrm{OR}=0.7, \mathrm{CI}=0.4-1.5)$. On the hand, the study established that females were more likely to suffer from Sexually Transmitted Infection (STIs) (OR=1.4, CI=0.36.0), gynaecological disorders $(\mathrm{OR}=1.5, \mathrm{CI}=0.5-4.5), \mathrm{HIV}(\mathrm{OR}=1.9, \mathrm{CI}=0.6-6.6)$, and unwanted pregnancies $(\mathrm{OR}=2.3, \mathrm{CI}=0.7-8.1)$ compared to males. There is an urgent need to deal with the problems of SBV by preventing and stopping it. There should be a collaborative approach between all the stakeholders including the community, ministries of Medical Services and Public Health \& Sanitation, private and non-governmental organization in dealing with sexual based violence and health implications resulting from it.
\end{abstract}

Keywords: Sexual based violence, health implications, survivors, males

DOI: $10.7176 / \mathrm{JHMN} / 66-03$

Publication date:September $30^{\text {th }} 2019$

\section{Introduction}

Sexual based violence ${ }^{1}$ is a pervasive global health problem (Keesbury et al., 2011; Raifman, et al., 2011; Keesbury \& Askew, 2010, and Government of Kenya (GoK), 2010). Sexual violence affects millions across the globe. It is a medical emergency, brutally shattering the lives of women, men and children. It destroys families and damages communities (Médecins Sans Frontières, 2009). Worldwide, men experience higher levels of physical violence than women as a result of war, gang-related activity, street violence, and suicide, while women and girls are more likely to be assaulted or killed by someone they know, such as an intimate partner (Raifman, et al., 2011; Keesbury \& Askew, 2010; Nakijoba, 2009; Kilonzo et al., 2009; Mugawe \& Powell, 2006). At least one out of every three women around the world has been beaten, coerced into sex, or otherwise abused in her lifetime, with the abuser usually someone known to her (Raifman, et al., 2011; Keesbury \& Askew, 2010; Heise, 2008; IGWG, 2006; General Assembly, 2006; World Bank, 2005). It is estimated that worldwide, one in five women will become a victim of rape or attempted rape in her lifetime (Alcalá, 2005). Perhaps the most pervasive human rights violation that we know today, it devastates lives, fractures communities, and stalls development. According to the WHO (2005), between $16 \%$ and $59 \%$ of women from Africa had ever experienced sexual violence from intimate partners (WHO, 2005). In South Africa, a sex crime happens every twenty seconds (World Bank, 2005).

\footnotetext{
${ }^{1}$ Any sexual act, attempt to obtain a sexual act, unwanted sexual comments or advances, or acts to traffic women's sexual, using coercion, threats of harm or physical force, rape of adult and adolescent men and women, and child sexual abuse, by any person regardless of the relationship to the survivor, in any setting, including but not limited to home or work place. It Includes rape, forced prostitution, vaginal, anal, or oral penetration, Sexual trafficking, sexual intercourse that one says no to.
} 
Reported incidents of rapes in 12 African provinces increased from 182 in 2001 to 270 in the year 2002 (World Bank, 2005). Available data, while limited, demonstrate the impact of the 'dual epidemics' of sexual and gender based violence and Human Immunodeficiency Virus (HIV) in sub-Saharan Africa (Keesbury and Askew, 2010). Cases of sexual based violence in Kenya have risen significantly (Onyango et al., 2009). Rape occurs every half hour in Kenya (Onyango et al., 2009). Sexual violence is mostly associated with females where males are taken as perpetrators with less regard to male sexual violence where females and males are perpetrators. This study investigated gender disparities in health consequences among survivors of sexual based violence.

\section{MATERIALS AND METHODS}

This study used a cross-sectional study design in three randomly selected provincial hospitals in Kenya. The study used both quantitative and qualitative methods to investigate the prevalence and health implications of sexual violence among survivors. Quantitative methods ensured high levels of reliability of gathered data while Qualitative method allowed for obtaining more in-depth information about SBV.

\subsection{The study area}

The study involved Nairobi Women's Hospital (NWH), Nyanza Provincial General Hospital (NPGH) and Coast Provincial General Hospital (CPGH) in Kenya. Nairobi woman Hospital is situated in Nairobi city, Nairobi province. Nairobi being the capital city of Kenya is located on $1^{0} 17^{\prime} 0^{\prime \prime} \mathrm{S}, 36^{\prime} 49^{\prime} 0^{\prime \prime} \mathrm{E}$. The city, which also forms the Nairobi province, lies on the Nairobi River in the south of the nation and has an elevation of 1661 metres (5450 $\mathrm{ft}$ ) above sea-level. Nyanza Provincial General Hospital is located in the city of Kisumu in western Kenya, Nyanza province. Kisumu is a Port City in western Kenya located on $0^{\circ} 6^{\prime} 0^{\prime \prime} \mathrm{S} / 34^{\circ} 45^{\prime} 0^{\prime \prime} \mathrm{E}$ and has elevation of $1,131 \mathrm{~m}$ $(3,711 \mathrm{ft})$ above sea-level. Coast Provincial General Hospital is located in the city of Mombasa in south-eastern Kenya, on the coast of the Indian Ocean. Mombasa is the second-largest City in Kenya located on $4^{\circ} 3^{\prime} 0^{\prime \prime} \mathrm{S} / 39^{\circ}$ 40 ' 0 " E.

\subsection{Target and study population}

The target population for this study were composed of survivors of sexual based violence accessing Nairobi Women Hospital, Nyanza and Coast provincial General Hospital for treatment, preventive therapies, and psychological support. They included patients and health workers.

\subsection{Sampling Procedure}

Random sampling was used to determine the study hospitals i.e. Nairobi Women Hospital, Nyanza provincial General Hospital, and Coast Provincial General Hospital. Systematic sampling was then used to select 280 survivors as the final sample based on the selection of every second survivor visiting the hospital on the day of the field work. This is an equal-probability method, in which every $k^{\text {th }}$ survivor (every second survivor) was selected, where $k$, the sampling interval, was calculated as:

$$
k=\frac{N}{n}
$$

Where $n$ is the sample size, and $N$ is the population size. Using the formula, $\mathrm{k}=1.5$ for each hospital (such as 100/65, 230/150 and 100/65 for CPGH, NWH and NPGH respectively) and therefore approximately 2 meaning every second survivor. Therefore each survivor had equal probability of being selected. Where a patient was not interested in being included in the study, the next patient was considered instead. The health workers were randomly selected from the duty roster of the day from among health workers who were involved in the management of sexual violence. The health workers were randomly selected from the duty roster of the day from care providers to victims of sexual violence. Information from lay counsellors at the health facilities was used to recruit the participants for the focus group discussions (FGDs) ${ }^{1}$ with survivors of sexual violence.

\subsection{Data collection instruments}

A semi-structured, open-ended a closed interview schedule questionnaire was developed with flexible probing, ideal for investigating personal experiences on sexual based violence from the subjective perspective of each respondent. This collected both qualitative and quantitative data. Observational checklists and notes were designed, taken and later used in data analysis. The notes were used to help fill in any gaps in the data obtained during FGDs or in-depth interviews. Focus group discussion guide was developed and used mainly to collect qualitative data. Choice methods were carefully done in line with sensitive studies of the same kind elsewhere (Action for

\footnotetext{
${ }^{1}$ Three focus group discussions (one from each study area) were conducted.
} 
Development (ACFODE), 2009; United Nations Fund for Women (UNIFEM), 2008; Ellsberg M, and Heise L., 2005; National Family Health Survey Report of India, 2005).

\subsection{Methods of data collection}

Interviews were conducted with survivors of sexual based violence at the study site. During the survey, the research team upheld the research ethical value of confidentiality and assured respondents of confidentiality of their responses and that information would not be used for anything else other than the study. Written consent was sought from the study participants.

Every second patient visiting the hospital on the day of the field work was selected for data collection. Where a patient was not willing to be included in the study, the next patient was considered instead. Interviews were conducted by recruited research assistant who was also a counsellor with experience of handling sexual based survivors, in a room provided by the Hospital within where the victims were managed from. Semi-structured interview schedules were used to collect data from survivors of sexual based violence and health workers. Interviews were conducted specifically for this study. The Focused Group Discussions (FGDs) were conducted with sexual violence survivors and with representatives of the local community.

\subsection{Ethical considerations}

Approvals from Kenyatta University's graduate school, National Council of Science and Technology and the Medical Officer of Health/Medical Superintendents and ethical committees from the selected Hospitals were obtained to undertake this study. Effort was made to ensure that the research process complied with the National Health and Medical Research Council guidelines for research involving humans (Ministry of Health (MoH), 2007). Because of the sensitivity of the study, all participants gave a written and verbal informed consent to participate in the study. In the case of children under 18 years, parents or legal guardians gave consent where possible. Survivors did not give consent were not enrolled in the study. During the survey, the research team upheld the research ethical value of confidentiality and assured respondents of confidentiality of their responses and that information would not be used for anything else other than the study. This was still held in the reporting of findings and preparation of the survey report. Individual identifications were not used to guarantee anonymity of the respondents.

\subsection{Data management and analysis}

The study generated both qualitative and quantitative data. These data were managed in a relational Access database and analysed using Statistical Package for Social Sciences (SPSS) version 17. Quantitative data were initially stored in an Access database (Microsoft Access, 2007). The Pearson's Chi-square test was used to show associations between independent and dependent variables. The $95 \%$ confidence intervals were estimated by maximum likelihood ratio. Logistic regression was used to establish the relationship between several independent or predictor variables and a dependent or criterion variable. All the qualitative data were recorded and verified during the interview; focus group discussions were summarized and documented. The qualitative data were then analyzed with a view to gaining understanding of the health implications of sexual violence.

\section{RESULTS AND DISCUSSION}

\subsection{Socio-Demographic Characteristics of the study population}

Table 1 presents the socio-demographic characteristics of sexual based violence survivors. Overall, a total of 280 survivors in three provincial hospitals (Coast Provincial General Hospital (CPGH), Nairobi Women Hospital (NWH), and Nyanza Provincial General Hospital (NPGH) were enrolled in the study.

The result indicated that $55.4 \%$ of minors ( $<18$ years) compared to adults $(44.6 \%)$ were sexually abused. The overall mean age of survivors was 19 years with the highest mean survivor age being in NWH (22.2) followed by NPGH (16.4) and the least was CPGH (14.6).The study found out that the youngest survivor was 2 months old while the oldest survivor was 68 years. There was significant difference between the prevalence of child survivors and the adult survivors $(\mathrm{p}=0.011)$ (Table 1$)$.

It would appear that young people and children were the target by perpetrators.

The results indicate that the proportion of females compared to that of males was consistently higher in all the three study areas $(\mathrm{CPGH}=53(81.5 \%), \mathrm{NWH}=121(80.7 \%), \mathrm{NPGH}=62(95.4 \%)($ Table 4.1$)$. The proportions of females to males differed significantly $(\mathrm{p}<0.001)$. 
Table 1: Socio- Demographic characteristics of the study population.

\begin{tabular}{|c|c|c|c|c|}
\hline Investigative Variable & $\bar{~} \mathrm{CPGH}, \mathrm{n}=65$ & NWH, $n=150$ & NPGH, $n=65$ & Total, n(\%) \\
\hline \multicolumn{5}{|l|}{ Survivor type } \\
\hline Minors ( $<18$ years) & $48(73.8)$ & $68(45.3)$ & $39(60)$ & $155(55.4)$ \\
\hline Adult & $17(26.2)$ & $82(54.7)$ & $26(40)$ & $125(44.6)$ \\
\hline \multicolumn{5}{|l|}{ Sex } \\
\hline Female & $53(81.5)$ & 121(80.7) & $62(95.4)$ & $236(84.3)$ \\
\hline Male & $12(18.5)$ & $29(19.3$ & $3(4.6)$ & $44(15.7)$ \\
\hline \multicolumn{5}{|l|}{ Education level } \\
\hline Primary and below & $51(78.5)$ & $69(46)$ & $34(52.3)$ & $154(55)$ \\
\hline Post secondary level & $3(4.6)$ & $47(31.4)$ & $16(24.6)$ & $66(23.6)$ \\
\hline Secondary level & 11(16.9) & $34(22.7)$ & $15(23.1)$ & $60(21.4)$ \\
\hline \multicolumn{5}{|l|}{ Marital status } \\
\hline Unmarried & 61(93.9) & $1118(78.7)$ & 62(95.4) & $241(86.1)$ \\
\hline Married & $4(6.2)$ & $32(21.3)$ & $3(4.6)$ & $39(13.9)$ \\
\hline \multicolumn{5}{|l|}{ Occupation } \\
\hline Student/Pupil & $30(46.2)$ & $51(34)$ & $29(44.6)$ & $110(39.3)$ \\
\hline Unemployed & $22(33.8)$ & $32(21.3)$ & $19(29.2)$ & $73(26.1)$ \\
\hline Business & $6(9.2)$ & $20(13.3)$ & $7(10.8)$ & $33(11.8)$ \\
\hline Casual labour & $4(6.2)$ & $16(10.7)$ & $5(7.7)$ & $25(8.9)$ \\
\hline Office & $1(1.5)$ & $20(13.3)$ & $2(3.1)$ & $23(8.2)$ \\
\hline Housewife & $2(3.1)$ & $11(7.3)$ & $3(4.6)$ & $16(5.7)$ \\
\hline
\end{tabular}

Approximately (41.4\%) of the respondents had less than elementary education majority of whom were from $\{\mathrm{CPGH}=51(78.5 \%), \mathrm{NWH}=69(46 \%)$ and $\mathrm{NPGH}=34(52.3 \%\} \mathrm{CPGH}$. It was found out that $66(23.6 \%)$ of the respondents had attained post secondary level of education $\{\mathrm{NWH}=47(31.4 \%), \mathrm{NPGH}=16(24.6 \%)$ and $(\mathrm{CPGH}$ $=3(4.6 \%\}$. only $60(21.4 \%)$ had achieved secondary level of education (Table 1$)$.

With regard to occupation, majority of the survivors were students or pupils $110(39.3 \%)$. About $73(26.1 \%)$ were unemployed, 33(11.8\%) business people, 25(8.9\%) casual labourers, 23 (8.2\%) Office, and 16(5.7\%) (Table 4.1).

On marital status, the result showed that the highest number of survivors $241(86.1 \%)$ were unmarried while $39(13.9 \%)$ married. It appeared that unmarried were most susceptible to sexual violence (Table 4.1).

For majority of the respondents $(84.3 \%)$, this was their first time to be involved in sexual SBV (Figure 1). There was no significant difference between the proportion of female $(86 \%)$ and male $(77 \%)$ survivors who reported first time experience $(\mathrm{p}=0.164)$.

Many perpetrators of SBV were people known to the victims 163(58\%), and strangers $117(42 \%)$. Approximately 141(60\%) of female and male 22(50\%) survivors reported that they were sexually abused by people known to them. Figure 1 indicates that perpetrators of SBV who were well known to the survivors. They included male/female friends $88(31 \%)$, fathers $30(10 \%)$, cousins $(23 \%)$, father in law $7(3 \%)$, mothers $5(2 \%)$, pastors $5(2 \%)$, employers 2(1\%), and former husbands 2(1\%) (Figure 1). 


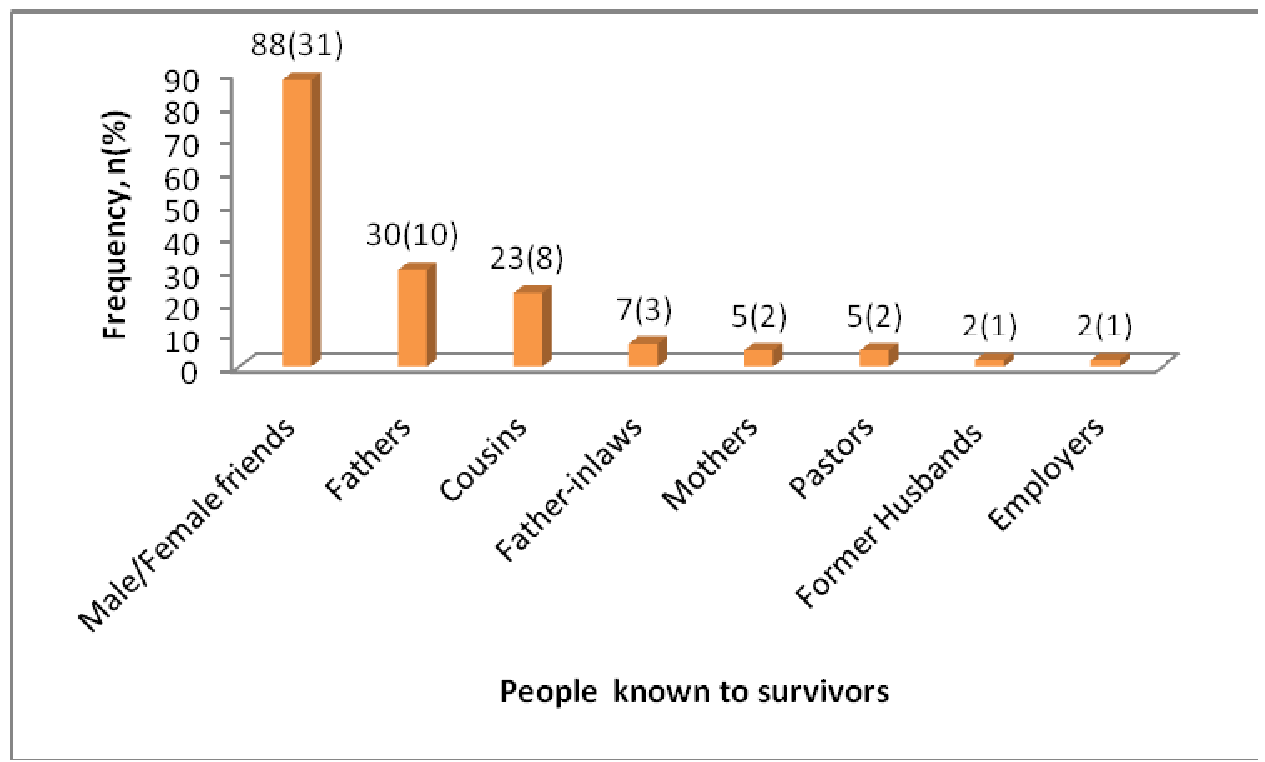

Figure 1: Proportion of perpetrators of SBV known to survivors.

\subsection{Health implications of sexual based violence.}

The study revealed that sexual based violence resulted into health consequences $(76.8 \%)$ among the survivors. The proportions of survivors with health problems due to SBV were high in all the study areas (NPGH $=92 \%, \mathrm{NWH}$ $=72 \%$ and $\mathrm{CPGH}=70 \%$ ) (Figure 2 ).

The study established that health problems significantly occurred in the study areas $(\mathrm{P}=0.003)$. The likelihood of a survivor reporting a health problem in $\mathrm{CPGH}$ was almost equal with that of $\mathrm{NWH}(\mathrm{OR}=0.9, \mathrm{CI}=0.5-1.7)$. The proportion of survivors who reported health problems at NPGH significantly differed with those from CPGH $(p=0.002)$. New Nyanza Provincial General Hospital was more likely to experience reported cases of health problems compared to $\mathrm{CPGH}$ and $\mathrm{NWH}(\mathrm{OR}=5.0, \mathrm{CI}=1.6-16.6$ and $\mathrm{OR}=4.5, \mathrm{CI}=1.6-13.8)$.

The results showed that the proportion of females $(79 \%)$ and males $(76 \%)$ who developed health complications were not significantly different $\left(\chi^{2}=0.223 ; \mathrm{df}=1 ; \mathrm{p}=0.637\right)$ (Figure 4.5). However males were 1.2 time more likely to develop health complications than female $(\mathrm{OR}=1.2, \mathrm{CI}=0.5-2.7)$. The study did not establish a significant association between health complications and the age of the survivors $(\mathrm{p}=0.892)$.

\subsection{Types of Complications}

The study revealed that SBV resulted into various types of health problems ranging from psychological trauma 143(51\%), physical injuries 75(27\%) to unwanted pregnancies 17(6\%) (Figure 3). Psychological trauma 143(51\%) was the most reported health problem $\{\mathrm{CPGH}=24(37 \%), \mathrm{NWH}=66(44 \%), \mathrm{NPGH}=53(81 \%)\}$ (Figure 3 and Table 2).

The result showed that the health problems reported differs significantly from one study area to another apart from gastrointestinal disorder $\left(\chi^{2}=3.184 ; \mathrm{df}=2 ; \mathrm{p}=0.204\right)$ (Table 2). Psychological trauma was much more reported in NPGH 53(81\%), physical injuries was most reported in CPGH 29(45\%), and STIs in NWH 27(18\%), and HIV $8(5 \%)$ (Table 2) 


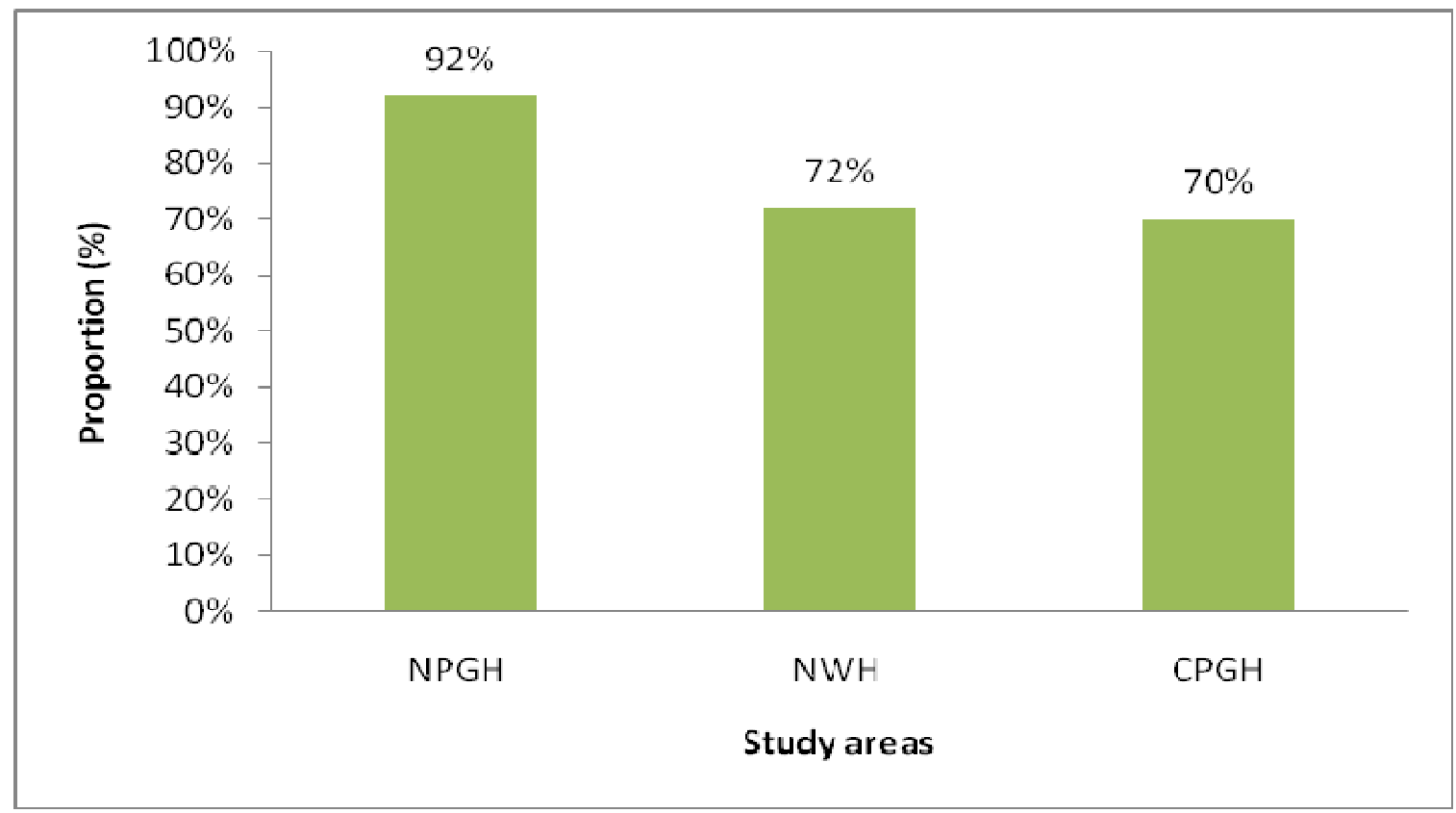

Figure 2: Proportion of survivors who developed health problems in the study areas.

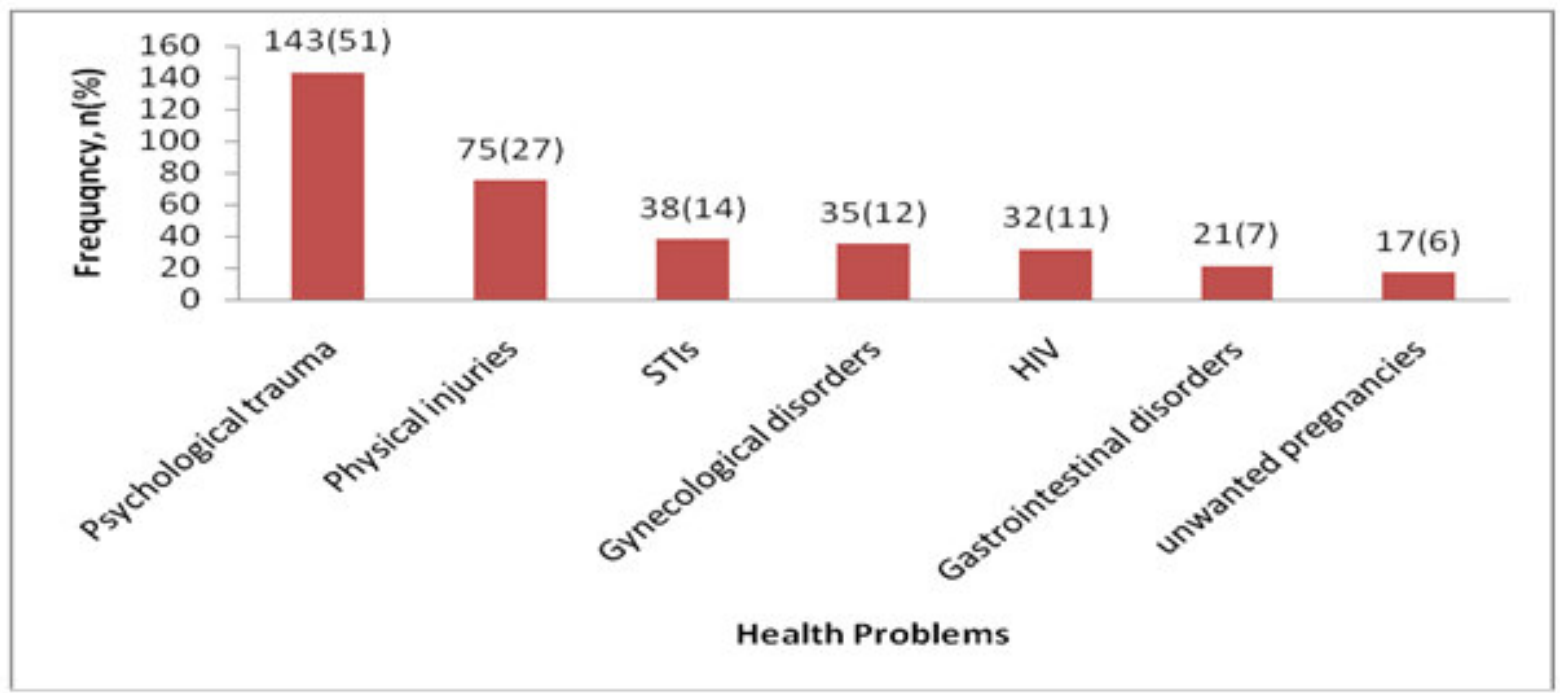

Figure 3: Types of health complications suffered by survivors.

Table 2: Health problems suffered by survivors in relation to study area.

\begin{tabular}{|l|c|c|c|l|}
\hline Health problems & CPGH, n (\%) & NWH, n (\%) & NPGH, n (\%) & Test of significance \\
\hline Psychological trauma & $24(37)$ & $66(44)$ & $53(81)$ & $\chi^{2}=32.354 ; \mathrm{df}=2 ; \mathrm{p}<0.001$ \\
\hline Physical injuries & $29(45)$ & $30(20)$ & $16(25)$ & $\chi^{2}=14.215 ; \mathrm{df}=2 ; \mathrm{p}=0.001$ \\
\hline STIs & $4(6)$ & $27(18)$ & $7(11)$ & $\chi^{2}=5.992 ; \mathrm{df}=2 ; \mathrm{p}=0.050$ \\
\hline Gynaecological disorders & $10(15)$ & $23(15)$ & $2(3)$ & $\chi^{2}=6.872 ; \mathrm{df}=2 ; \mathrm{p}=0.032$ \\
\hline HIV & $2(3)$ & $25(17)$ & $5(8)$ & $\chi^{2}=9.441 ; \mathrm{df}=2 ; \mathrm{p}=0.009$ \\
\hline Gastrointestinal disorders & $8(12)$ & $8(5)$ & $5(8)$ & $\chi^{2}=3.184 ; \mathrm{df}=2 ; \mathrm{p}=0.204$ \\
\hline Unwanted pregnancies & $3(5)$ & $14(9)$ & $0(0)$ & $\chi^{2}=7.242 ; \mathrm{df}=2 ; \mathrm{p}=0.027$ \\
\hline
\end{tabular}

The proportion of females and males with health problems did not differ significantly except for gastrointestinal disorders which differed significantly $(\mathrm{P}<0.001)$ (Table 3$)$. Males were more likely to suffer from psychological trauma, physical injuries and gastrointestinal injuries compared to females $(\mathrm{OR}=1.2, \mathrm{CI}=0.6-2.2$; $\mathrm{OR}=0.2, \mathrm{CI}=0.1-5.0$; and $\mathrm{OR}=0.7, \mathrm{CI}=0.4-1.5)($ Table 3$)$. On the hand, the study established that females were more likely to suffer from STIs $(\mathrm{OR}=1.4, \mathrm{CI}=0.3-6.0)$, gynaecological disorders $(\mathrm{OR}=1.5, \mathrm{CI}=0.5-4.5), \mathrm{HIV}$ $(\mathrm{OR}=1.9, \mathrm{CI}=0.6-6.6)$, and unwanted pregnancies $(\mathrm{OR}=2.3, \mathrm{CI}=0.7-8.1)$ compared to males (Table 3$)$. 
Table 3: Health problems by survivors in relation to study area

\begin{tabular}{lccccc}
\hline \hline & \multicolumn{2}{c}{ Sex } & & \\
\cline { 2 - 3 } Health problems & Female, n (\%) & Male, n (\%) & & OR (95\% CI) & p-value \\
\hline \hline Psychological trauma & $122(52)$ & $21(58)$ & & $1.2(0.6-2.2)$ & $\mathrm{P}=0.629$ \\
Physical injuries & $61(26)$ & $14(32)$ & & $0.7(0.4-1.5)$ & $\mathrm{P}=0.674$ \\
STIs & $35(15)$ & $3(7)$ & & $2.3(0.7-8.1)$ & $\mathrm{P}=0.154$ \\
Gynaecological disorders & $31(13)$ & $4(9)$ & & $1.5(0.5-4.5)$ & $\mathrm{P}=0.546$ \\
HIV & $29(12)$ & $3(7)$ & & $1.9(0.6-6.6)$ & $\mathrm{P}=0.295$ \\
Gastrointestinal disorders & $12(5)$ & $9(20)$ & & $0.2(0.1-5.0)$ & $\mathrm{P}<0.001$ \\
Unwanted pregnancies & $15(6)$ & $2(4)$ & & $1.4(0.3-6.0)$ & $\mathrm{P}=0.644$ \\
\hline \hline
\end{tabular}

On examining the proportion of those who had various health problems between children ( $<18$ years) and adults $(>18$ years), there was no significant differences between them except for gynaecological disorders $\left(\chi^{2}=5.799 ; \mathrm{df}=1 ; \mathrm{p}=0.016\right)$ (Table 4). Female children were 2.5 time more at risk of suffering from gynaecological disorders $(\mathrm{OR}=2.5, \mathrm{CI}=1.2-5.7)$. The risk of suffering from physical injuries, STIs and HIV after SBV was almost equal between adults and children $(\mathrm{OR}=0.9, \mathrm{CI}=0.5-1.5 ; \mathrm{OR}=0.8, \mathrm{CI}=0.4-1.5$; and $\mathrm{OR}=0.9, \mathrm{CI}=0.4-1.9$ respectively) (Table 4).

Table 4: Proportion of children and adults who suffered health problems

\begin{tabular}{lccccc}
\hline \hline & \multicolumn{2}{c}{ Groups } & & \\
\cline { 2 - 3 } Health problems & Child, n (\%) & Adult, n (\%) & OR (95\% CI) & p-value \\
\hline \hline Psychological trauma & $72(46)$ & $71(57)$ & & $0.7(0.4-1.1)$ & $\mathrm{P}=0.085$ \\
Physical injuries & $40(26)$ & $35(28)$ & & $0.9(0.5-1.5)$ & $\mathrm{P}=0.680$ \\
STIs & $19(12)$ & $19(15)$ & $0.8(0.4-1.5)$ & $\mathrm{P}=0.475$ \\
Gynaecological disorders & $26(17)$ & $9(7)$ & $2.5(1.2-5.7)$ & $\mathrm{P}=0.016$ \\
HIV & $17(11)$ & $15(12)$ & $0.9(0.4-1.9)$ & $\mathrm{P}=0.787$ \\
Gastrointestinal disorders & $8(5)$ & $13(10)$ & & $0.5(0.2-1.2)$ & $\mathrm{P}=0.098$ \\
Unwanted pregnancies & $11(7)$ & $6(5)$ & $1.5(0.5-4.2)$ & $\mathrm{P}=0.424$ \\
\hline \hline
\end{tabular}

\subsubsection{Types of physical injuries}

Soft tissue injuries 49(17\%) mainly featured among people who suffered physical injuries as a result of SBV. Other injuries included limb injuries 13(5\%), injuries on the anal region 9(3\%) and pelvic pain 7(2\%) (Figure 4). One elderly mother said "sexual abuse make one disoriented physically and psychologically, making one not to mention it for long because of the fear of how she will be seen and what people will say about her. Sexual violence hurt victims physically and psychologically".

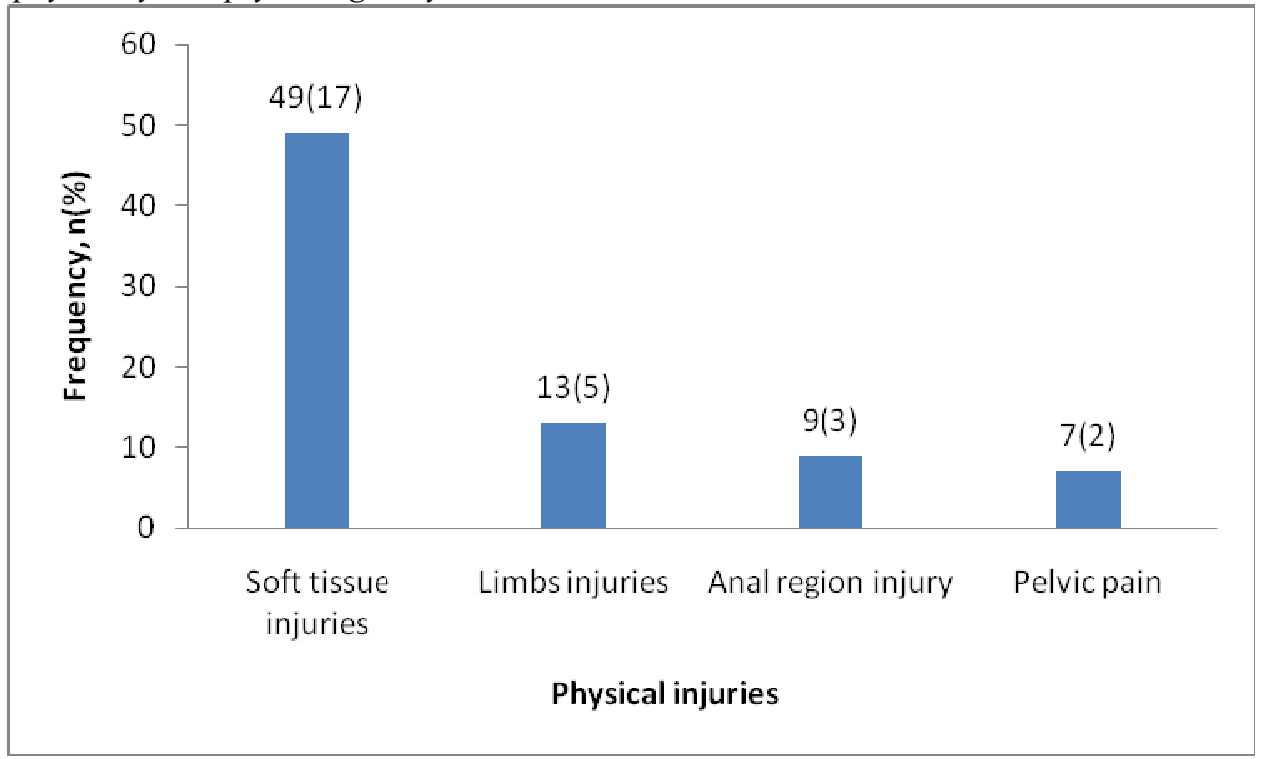

Figure 4: Proportion of survivors who suffered from physical injuries.

The results showed that there was significant differences in the proportion of survivors who had soft tissue injuries $\left(\chi^{2}=10.502 ; \mathrm{df}=2 ; \mathrm{p}=0.005\right)$, anal region injuries $\left(\chi^{2}=6.493 ; \mathrm{df}=2 ; \mathrm{p}=0.039\right)$ and limbs injuries $\left(\chi^{2}=11.363\right.$; $\mathrm{df}=2 ; \mathrm{p}=0.003)$ in the study areas. There was no significant difference in the proportion of survivors who reported pelvic pain in $\mathrm{CPGH}, \mathrm{NWH}$ and $\mathrm{NPGH}\left(\chi^{2}=1.594 ; \mathrm{df}=2 ; \mathrm{p}=0.451\right)$ (Table 5). 
Table 5: Proportion of survivors with physical injuries in various study areas

\begin{tabular}{lcccl}
\hline \hline Type of physical injuries & CPGH, n (\%) & NWH, n (\%) & NPGH, n (\%) & Test of significance \\
\hline \hline Soft tissue injuries & $17(29)$ & $16(11)$ & $16(25)$ & $\chi^{2}=10.502 ; \mathrm{df}=2 ; \mathrm{p}=0.005$ \\
Anal region injury & $5(8)$ & $4(3)$ & $0(0)$ & $\chi^{2}=6.493 ; \mathrm{df}=2 ; \mathrm{p}=0.039$ \\
Pelvic pain & $1(1)$ & $3(2)$ & $3(5)$ & $\chi^{2}=1.594 ; \mathrm{df}=2 ; \mathrm{p}=0.451$ \\
Limbs injuries & $8(12)$ & $4(3)$ & $1(1)$ & $\chi^{2}=11.363 ; \mathrm{df}=2 ; \mathrm{p}=0.003$ \\
\hline \hline
\end{tabular}

In examining the physical injuries among gender, females were more at risk of suffering from soft tissue injuries $(\mathrm{OR}=2.4, \mathrm{CI}=0.2-6.9)$. Males were more at risk of suffering from anal region injuries $(\mathrm{OR}=0.2, \mathrm{CI}=0.0$ 1.6) and limbs injuries $(\mathrm{OR}=3.0, \mathrm{CI}=0.8-0.9)$ compared to females (Table 6).

Table 6: Proportion of female and male with various types of injuries

\begin{tabular}{lccccc}
\hline \hline & \multicolumn{2}{c}{ Sex } & & \\
\cline { 2 - 3 } Type of injuries & Female, n (\%) & Male, n (\%) & & OR (95\% CI) & p-value \\
\hline \hline Soft tissue injuries & $45(19)$ & $4(9)$ & & $2.4(0.2-6.9)$ & $\mathrm{P}=0.110$ \\
Anal region injuries & $1(.4)$ & $8(18)$ & & $0.2(0.0-1.6)$ & $\mathrm{P}<0.001$ \\
Limbs injuries & $8(3)$ & $5(11)$ & $3.0(0.8-0.9)$ & $\mathrm{P}=0.021$ \\
Pelvic pain & $6(2)$ & - & - & - \\
\hline \hline
\end{tabular}

The study did not establish significant differences between females and males in regard to all types of physical injuries (Table 7). Both adults and children were almost equally vulnerable to soft tissue injuries $(\mathrm{OR}=0.9, \mathrm{CI}=$ $0.5-1.8)$.

Table 7: Types of physical injuries among children and adults

\begin{tabular}{lccccc} 
& \multicolumn{3}{c}{ Groups } & & \\
\cline { 2 - 4 } Type of injuries & Child, n (\%) & Adult, n (\%) & & OR (95\% CI) & p-value \\
\hline \hline Soft tissue injuries & $27(17)$ & $22(18)$ & & $0.9(0.5-1.8)$ & $\mathrm{P}=0.968$ \\
Anal region injuries & $7(4)$ & $2(1)$ & & $2.9(0.6-14.2)$ & $\mathrm{P}=0.169$ \\
Pelvic pain & $6(4)$ & $1(1)$ & & $5.0(0.6-42.0)$ & $\mathrm{P}=0.102$ \\
Limbs injuries & $5(3)$ & $8(6)$ & & $0.5(0.1-1.5)$ & $\mathrm{P}=0.210$ \\
\hline \hline
\end{tabular}

\subsubsection{Gynaecological disorders}

The types of gynaecological problems $35(12 \%)$ reported are shown in figure 5.

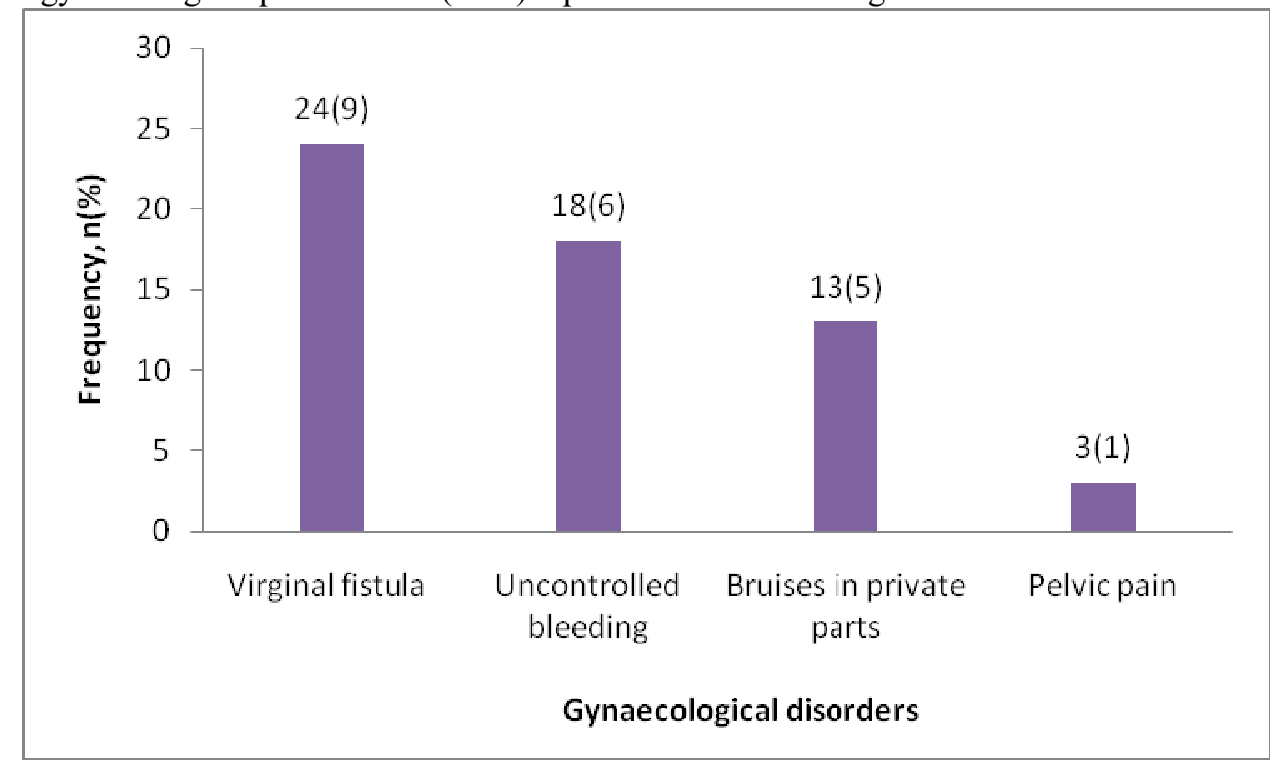

Figure 5: Proportion of survivors with various gynaecological disorders.

Majority of the respondents reported virginal fistula 24(9\%), and others including uncontrolled bleeding $18(6 \%)$, bruises in private parts $13(5 \%)$ and pelvic pain $3(1 \%)$ (Figure 5 and Table 8 ). 
Table 8: Proportion of survivors with various gynaecological disorders in the study areas.

\begin{tabular}{lcccc}
\hline \hline Gynaecological disorders & CPGH, n (\%) & NWH, n (\%) & NPGH, n (\%) & Test of significance \\
\hline \hline Virginal fistula & $8(12)$ & $15(10)$ & $1(1)$ & $\chi^{2}=5.651 ; \mathrm{df}=2 ; \mathrm{p}=0.059$ \\
Uncontrolled bleeding & $5(8)$ & $12(8)$ & $1(1)$ & $\chi^{2}=3.372 ; \mathrm{df}=2 ; \mathrm{p}=0.185$ \\
Bruises in private parts & $1(1)$ & $10(7)$ & $2(3)$ & $\chi^{2}=3.163 ; \mathrm{df}=2 ; \mathrm{p}=0.206$ \\
Pelvic pain & $0(0)$ & $2(1)$ & $1(1)$ & $\chi^{2}=0.935 ; \mathrm{df}=2 ; \mathrm{p}=0.627$ \\
\hline \hline
\end{tabular}

Most of the health workers interviewed pointed out that gynaecological disorders treated in the study hospitals included Bruises in private parts 28(76\%), Uncontrolled bleeding 26(70\%), Virginal fistula 21(57\%), pelvic inflammatory disease (PID) 22(60\%), Pelvic pain 23(62\%) (Table 9). Pelvic inflammatory disease was a health problem commonly mentioned by key informants in all study areas $\{\mathrm{CPGH}=6(50 \%), \mathrm{NWH}=9(75 \%), \mathrm{NPGH}=$ $7(54 \%)\}$ and which was never mentioned by survivors.

Table 9: Gynaecological disorders by key informants in the study areas

\begin{tabular}{lccccc}
\hline \hline Gynaecological disorders & CPGH, n (\%) & NWH, n (\%) & NPGH, n (\%) & Total, n (\%) & Significance \\
\hline \hline Bruises in private parts & $10(83)$ & $10(83)$ & $8(61)$ & $28(76)$ & $\mathrm{p}=0.337$ \\
Uncontrolled bleeding & $9(75)$ & $9(75)$ & $8(61)$ & $26(70)$ & $\mathrm{p}=0.694$ \\
Virginal fistula & $8(67)$ & $8(67)$ & $7(74)$ & $23(62)$ & $\mathrm{p}=0.745$ \\
PID & $6(50)$ & $9(75)$ & $7(54)$ & $22(60)$ & $\mathrm{p}=0.403$ \\
Pelvic pain & $6(50)$ & $8(67)$ & $7(54)$ & $21(57)$ & $\mathrm{p}=0.688$ \\
\hline \hline
\end{tabular}

There was a noted significant differences in female children and adults regarding virginal fistula $(\mathrm{p}=0.043)$ and bruises in the private parts $(\mathrm{p}=0.030)$ (Table 10). Children had a higher risk of getting all the gynaecological disorders compared to adults (Table 10).

Table 10: Proportion of children and adult survivors with different gynaecological disorders

\begin{tabular}{lccccc}
\hline \hline & \multicolumn{3}{c}{ Groups } & & \\
\cline { 2 - 3 } Gynaecological disorders & \multicolumn{1}{c}{ Child, $\mathbf{n}(\%)$} & Adult, n (\%) & & OR (95\% CI) & p-value \\
\hline \hline Virginal fistula & $12(8)$ & $6(5)$ & & $2.6(1.0-6.8)$ & $\mathrm{P}=0.043$ \\
Uncontrolled bleeding & $12(8)$ & $6(5)$ & & $1.7(0.6-4.6)$ & $\mathrm{P}=0.318$ \\
Bruises in private parts & $11(7)$ & $2(2)$ & & $4.7(1.0-21.6)$ & $\mathrm{P}=0.030$ \\
Pelvic pain & $3(2)$ & $0(0)$ & $1.8(1.6-2.0)$ & $\mathrm{P}=0.118$ \\
\hline \hline
\end{tabular}

\subsubsection{Gastrointestinal disorders}

The only gastrointestinal disorder $20(7 \%)$ reported by survivors was flatulence \{CPGH $=7(11 \%), \mathrm{NWH}=8(5 \%)$, NPGH $5(8 \%)\}$. This was confirmed by the key informants $18(49 \%)$ who also reported flatulence in all the study hospitals $\{\mathrm{CPGH}=5(42 \%), \mathrm{NWH}=6(50 \%), \mathrm{NPGH} 7(54 \%)\}$. There was no significant difference in reported cases of flatulence among survivors in the study areas $\left(\chi^{2}=2.059 ; \mathrm{df}=2 ; \mathrm{p}=0.357\right)$. There was a significant difference in reported cases of flatulence between females $12(5 \%)$ and males $8(18 \%)$. Males were more likely to report flatulence compared to female $(\mathrm{OR}=0.2, \mathrm{CI}=0.1-0.6)$. Adults $13(10 \%)$ were more likely report flatulence compared to children $7(4 \%)(\mathrm{OR}=0.4, \mathrm{CI}=0.1-1.0)$. However no significant difference was reported between children and adults $\left(\chi^{2}=3.612 ; \mathrm{df}=1 ; \mathrm{p}=0.557\right)$.

\subsubsection{Sexually transmitted infections}

Sexually transmitted infections 38(14\%) which were reported included HIV 35(12\%), syphilis 3(1\%), and urinary tract infection $1(0.4 \%)$ (Figure 6). One of the rape survivors said, "The most dangerous health issue today is HIV and AIDS infection which is all over. Many people are suffering from HIV/AIDS and you cannot tell who is infected and who is not infected." 


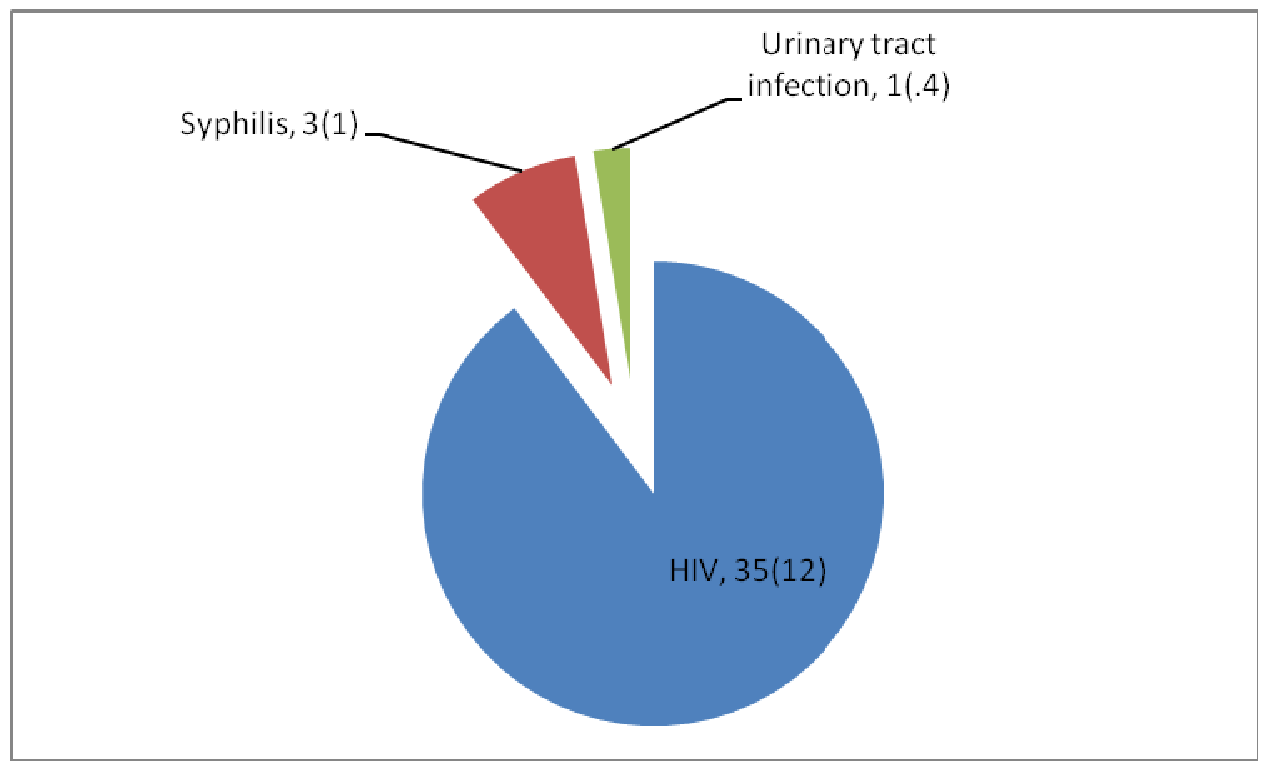

Figure 6: Types of STIs reported by survivors of SBV.

Table 11 shows the proportion of survivors who reported STIs in the study areas. There were no significant differences in the number of reported cases of STIs in the study areas.

Table 11: Proportion of survivors with STIs in the study areas

\begin{tabular}{lcccl}
\hline \hline STIs & CPGH, $\mathbf{n}(\%)$ & NWH, $\mathbf{n}(\%)$ & NPGH, $\mathbf{n}(\%)$ & Test of significance \\
\hline \hline HIV & $4(6)$ & $25(17)$ & $6(9)$ & $\chi^{2}=5.410 ; \mathrm{df}=2 ; \mathrm{p}=0.067$ \\
Syphilis & $0(0)$ & $2(1)$ & $1(1)$ & $\chi^{2}=0.935 ; \mathrm{df}=2 ; \mathrm{p}=0.627$ \\
Urinary tract infection & $0(0)$ & $1(1)$ & $0(0)$ & $\chi^{2}=0.870 ; \mathrm{df}=2 ; \mathrm{p}=0.647$ \\
\hline \hline
\end{tabular}

Key informants listed a number of STIs which resulted from SBV and treated in their hospitals (Table 12). They included HIV 29(78\%), Chlamydia 28(76\%), Chancroid 27(73\%), Candidiasis 27(73\%), Syphilis 26(70\%), Gonorrhoea 26(70\%), Genital herpes 20(54\%), Trichomoniasis 20(54\%), Human Papilla Virus 18(49\%), Hepatitis B $18(49 \%)$ and Urinary tract infection $16(43 \%)$. Some of these infections would not be mentioned by survivors due to lack of knowledge on them. The study found that, records were poorly kept as it was hard to trace previous data. However as from the time of this study, study hospitals had started to keep SBV information.

Table 12: Proportions of key informants with types of STIs in various study areas

\begin{tabular}{lccrrc}
\hline \hline STIs & CPGH, $\mathbf{n}(\%)$ & NWH, $\mathbf{n}(\%)$ & NPGH, $\mathbf{n}(\%)$ & Total & Test of significance \\
\hline \hline HIV & $10(83)$ & $8(67)$ & $11(85)$ & $29(78)$ & $\mathrm{p}=0.486$ \\
Chlamydia & $8(67)$ & $8(67)$ & $12(92)$ & $28(76)$ & $\mathrm{p}=0.222$ \\
Chancroid & $8(67)$ & $7(58)$ & $12(92)$ & $27(73)$ & $\mathrm{p}=0.135$ \\
Candidiasis & $8(67)$ & $7(58)$ & $12(92)$ & $27(73)$ & $\mathrm{p}=0.135$ \\
Syphilis & $8(67)$ & $7(58)$ & $11(85)$ & $26(70)$ & $\mathrm{p}=0.337$ \\
Gonorrhoea & $8(67)$ & $7(58)$ & $11(85)$ & $26(70)$ & $\mathrm{p}=0.135$ \\
Genital herpes & $6(50)$ & $5(41)$ & $9(69)$ & $20(54)$ & $\mathrm{p}=0.363$ \\
Trichomoniasis & $7(58)$ & $7(58)$ & $6(46)$ & $20(54)$ & $\mathrm{p}=0.777$ \\
Human P Virus & $6(50)$ & $6(50)$ & $6(46)$ & $18(49)$ & $\mathrm{p}=0.975$ \\
Hepatitis B & $6(50)$ & $6(50)$ & $6(46)$ & $18(49)$ & $\mathrm{p}=0.975$ \\
Urinary tract infection & $5(41)$ & $3(25)$ & $8(61)$ & $16(43)$ & $\mathrm{p}=0.182$ \\
\hline \hline
\end{tabular}

There was no significant difference between STIs cases in female and male $(\mathrm{p}=0.214)$, however female were at a higher risk of contracting STIs than males (Table 13).

Table 13: Cases of STIs among females and males

\begin{tabular}{|c|c|c|c|c|}
\hline \multirow[b]{2}{*}{ STIs } & \multicolumn{2}{|c|}{ Sex } & \multirow[b]{2}{*}{ OR $(95 \% \mathrm{CI})$} & \multirow[b]{2}{*}{ p-value } \\
\hline & Female, n (\%) & Male, n (\%) & & \\
\hline HIV & $32(14)$ & $3(7)$ & $2.1(0.6-7.3)$ & $\mathrm{P}=0.214$ \\
\hline Syphilis & $3(1)$ & $0(0)$ & $1.2(1.1-1.2)$ & $\mathrm{P}=0.452$ \\
\hline Urinary tract infection & $1(.4)$ & $0(0)$ & $1.2(0.1-1.2)$ & $\mathrm{P}=0.665$ \\
\hline
\end{tabular}

Whereas there was no significant difference in cases of infection between children and adults, the risk of contracting HIV was among adults $(\mathrm{OR}=0.7, \mathrm{CI}=0.4-1.5)$. Children stood a higher chance than adults to contract syphilis $(\mathrm{OR}=1.6, \mathrm{CI}=0.1-18.1)$ and urinary tract infections $(\mathrm{OR}=1.8, \mathrm{CI}=1.6-2.0)$. 


\subsubsection{Psychological consequences}

Psychological consequences 143(51\%) reported among the survivors of sexual based violence included fear 120(43\%), shame 91(32\%), depression 81(29\%), anxiety 53(19\%) and low-self esteem 46(16\%) (Figure 7)

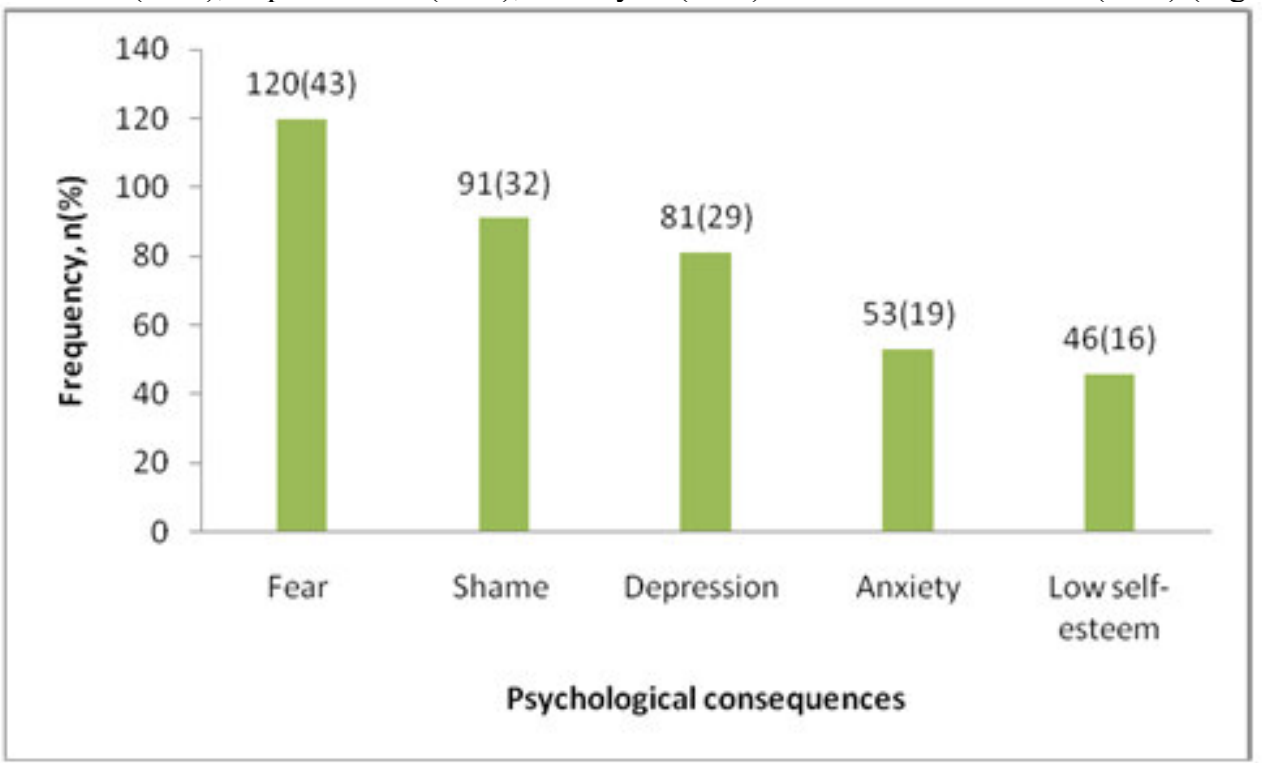

Figure 7: Proportion of survivors with psychological consequences.

The results show that reported cases of all the psychological consequences were significantly different from one study area to another (Table 14). New Nyanza Provincial Hospital reported the highest subjects with psychological consequences among the study areas. This would be attributed to socio-economic and cultural factors of survivors associated with sexual based violence.

Table 14: Proportion of survivors with psychological disorders in the various study areas.

\begin{tabular}{lcccc}
\hline \hline Psychological consequences & CPGH, n (\%) & NWH, n (\%) & NPGH, n (\%) & Test of significance \\
\hline \hline Fear & $17(26)$ & $52(35)$ & $51(78)$ & $\chi^{2}=45.160 ; \mathrm{df}=2 ; \mathrm{p}<0.001$ \\
Shame & $15(23)$ & $35(23)$ & $41(63)$ & $\chi^{2}=36.079 ; \mathrm{df}=2 ; \mathrm{p}<0.001$ \\
Depression & $20(31)$ & $32(21)$ & $29(45)$ & $\chi^{2}=12.096 ; \mathrm{df}=2 ; \mathrm{p}=0.002$ \\
Anxiety & $14(21)$ & $21(14)$ & $18(28)$ & $\chi^{2}=5.916 ; \mathrm{df}=2 ; \mathrm{p}=0.052$ \\
Low self - esteem & $8(12)$ & $19(13)$ & $19(29)$ & $\chi^{2}=10.109 ; \mathrm{df}=2 ; \mathrm{p}=0.006$ \\
\hline \hline
\end{tabular}

The study did not find significant differences in reported cases of psychological consequences between females and males (Table 15). Females were more likely than males to experience fear $(\mathrm{OR}=1.4, \mathrm{CI}=0.7-2.7)$ while males were more likely to experience shame $(\mathrm{OR}=0.8, \mathrm{CI}=0.4-2.7)$ and anxiety $(\mathrm{OR}=0.7, \mathrm{CI}=0.3-1.6)$. Depression and low self-esteem were likely to be experienced equally by both sexes.

Table 15: Proportion of females and male with psychological consequences

\begin{tabular}{lccccc}
\hline \hline & \multicolumn{2}{c}{ Sex } & & \\
\cline { 2 - 3 } Psychological consequences & Female, n (\%) & Male, n (\%) & OR (95\% CI) & p-value \\
\hline \hline Fear & $104(44)$ & $16(36)$ & & $1.4(0.7-2.7)$ & $\mathrm{P}=0.343$ \\
Shame & $75(32)$ & $16(36)$ & & $0.8(0.4-2.7)$ & $\mathrm{P}=0.551$ \\
Depression & $68(29)$ & $13(29)$ & & $1.0(0.5-1.9)$ & $\mathrm{P}=0.922$ \\
Anxiety & $43(18)$ & $10(23)$ & & $0.7(0.3-1.6)$ & $\mathrm{P}=0.484$ \\
Low self-esteem & $39(16)$ & $7(16)$ & & $1.0(0.4-2.5)$ & $\mathrm{P}=0.919$ \\
\hline \hline
\end{tabular}

The result of psychological consequences among children and adults indicated no significant difference in cases between them \{depression $(\mathrm{P}=0.122)$; shame $(\mathrm{P}=0.386)$; Low self-esteem $(\mathrm{P}=0.618)$; anxiety $(\mathrm{P}=0.839)$ and fear $(\mathrm{P}=0.890)\}$. However adults were more likely to experience shame $(\mathrm{OR}=0.8, \mathrm{CI}=0.5-1.3)$, and depression $(\mathrm{OR}=0.7, \mathrm{CI}=0.4-1.1)$. Children were more like to experience low self-esteem $(\mathrm{OR}=1.1, \mathrm{CI}=0.6-2.2)$. Fear and anxiety were likely to be experienced equally among children and adults $(\mathrm{OR}=1.0, \mathrm{CI}=0.6-1.7)$.

\section{DISCUSSION}

\subsection{Health Implications of Sexual Based Violence}

The study shows that both males and females experienced health consequences almost equally. These findings are consistent with studies done by Médecins Sans Frontières, (2009), Kilonzo, (2009). Population Council (2008) pointed out that contrary to female victims of sexual assault, male victims are likely to suffer from a range of 
health problems, both in the immediate period after the assault and over the longer term.

The study established that males were 1.2 time more likely to develop health complication than females. These findings were important in the sense that most male sexual based violence are underreported due to shame, guilt and fear. Various studies (Médecins Sans Frontières, 2009 and Bhandari, 2005) demonstrate that, myths and strong prejudices surrounding male sexuality also prevent men from coming forward. That means that they continue suffering silently without professional assistance.

Additionally, the study revealed that sexual violence resulted in serious health implications ranging from physical injuries, gynaecological disorders, psychological problems, to gastrointestinal disorders and sexually transmitted infections among others. This dovetails with the findings of other studies (Nakijoba, 2009; Population council, 2008, kilonzo, 2009; Médecins Sans Frontières, 2009) which list death, injuries, gynaecological disorders, unwanted pregnancy, adverse pregnancy outcomes, sexually transmitted infections including HIV and mental distress such as fear, shame and anxiety among others. In her presentation, Nakijoba (2009) reported that the effects of sexual based violence are enormous and multi-edged including physical, psychological, legal and economic and are realized at various levels: individual (by both victim and perpetrator), family, community and national levels. To mitigate all these effects of SBV, immediate medical response is required.

\subsection{Physical injuries}

Physical injuries reported included soft tissue injuries, limb injuries, and injuries on the anal region. The study found out that sexual violence hurt victims physically. The results showed that there were significant differences in the proportion of survivors who were physically injured. Highest proportions of soft tissue injuries, anal region injuries and limb injuries were from CPGH. Population health (2008), reported that some of this physical injuries would be life threatening and survivors of sexual abuse may have physical injuries that require immediate attention. Life threatening injuries take precedence over other components of medical management (Kenya Ministry of Health/Division of Reproductive Health, 2004; Kilonzo, \& Taegtmeyer, 2005;). The study found out that both females and males were almost the same in regard to all types of physical injuries. Both adults and children were vulnerable to injuries almost equally. As note earlier injuries resulted due to physical violence which included slapping, kicking, hitting, or use of weapons. These finds are the same as those documented by Population council, (2008). Population council (2009), noted that physical violence resulted to fractures, chronic pain syndromes, fybromyalgia, permanent disability, gastro-intestinal disorders among other problems.

\subsection{Reproductive health problems}

Reproductive health problems reported by participants of the study included: unwanted pregnancies, bruises in private parts, urinary tract infections, uncontrolled bleeding, virginal fistula, pelvic inflammatory disease (PID), and Pelvic pain. These problems were mainly for female. Girls ( $<18$ years) had a higher risk of suffering from all the gynaecological disorders compared to adult women. These findings are the same as those documented by Population council (2008); Campbell, et al., (2004); Campbell and Self, (2004); Garcia-Moreno, (2002). Population council (2011) notes that child marriage, and childbearing during childhood can have both immediate and lifelong repercussions. Population council (2009) found out that reproductive health problems related with SBV included urinary tract infections, unwanted pregnancy, pregnancy complications, vaginal bleeding, traumatic gynaecologic fistula, unsafe abortion, and chronic pelvic pain.

Female survivors of sexual violence not only sustain physical injuries, but are more likely than other women to have unintended pregnancies, report symptoms of reproductive tract infections (Campbell \& Self, 2004).

\subsection{Sexually transmitted infections}

Cases of sexually transmitted infections such as HIV, syphilis, urinary tract infection and gonorrhoea were reported. Other STIs included chlamydia, chancroid, candidiasis, syphilis, gonorrhoea, genital herpes, trichomoniasis, human P Virus, hepatitis B and Urinary tract infection. Sexually transmitted infections have been documented in various studies including Keesbury et al., (2011); Sajeda and Althea (2011); Keesbury and Askew (2010); Population council (2009); Population council (2008); Speight, et al. (2006); Ellis, et al., (2005); Fonck, et al., (2005); Kishor \& Johnson, (2004).

Female were at a higher risk of contracting STIs than males. These findings dovetail other studies (American Social Health Association, 1998; Institute of Medicine, 1997; Wong et al., 2004) which documented that Women are at higher risk than men for most STIs, and young women are more susceptible to certain infections than older women. Due to cervical ectopy that is extremely common in adolescent females, the immature cervix of adolescent females is covered with cells that are especially susceptible to STIs such as chlamydia.

The study did not find significant difference in the infection rates between children and adults. However the risk of contracting HIV was more among children. These findings were consistent with findings documented by Population council (2011) and Speight, et al. (2006). Data from Demographic and Health Surveys have shown that women who have suffered violence are twice more likely to have an STI than women who have not (Fonck, et al., 
2005). Female survivors of sexual violence are more likely than other women to have multiple partners, and less likely to use condoms and other contraceptives (Campbell \& Self, 2004).

\subsection{Psychological consequences}

Psychological consequences were mostly reported among the survivors of sexual based violence. Psychological problems reported included fear, shame, depression, anxiety and low-self esteem. These findings are the same as various studies on psychosocial consequences (Elson \& Keesbury, 2010; Ajema, et al., 2009; ESOG, 2009; Keesbury, et al., 2009; Tshwaranang Legal Advocacy Centre 2009; and Vetten, et al. 2008). New Nyanza Provincial Hospital in Nyanza reported the highest subjects of psychological consequenses among the study areas. The study did not find significant differences in reported cases of psychological consequences between females and males. However males were more likely to experience shame and anxiety compared to females. Females experienced fear more than males while depression and low self esteem were experienced equally among the two genders. Africa Regional Sexual and Gender-Based Violence Network Consultation (2008), pointed out that a greater proportion of male survivors expressing interest than female survivors when requested to join a support group.

Females were more likely than males to experience fear while males were more likely to experience shame and anxiety. Depression and low self-esteem were likely to be experienced equally by females and males. On examining psychological consequences adults were more likely to experience shame and depression than children. Children were more like to experience low self-esteem. Psychological trauma makes it difficult to take the necessary history and statements from the survivor, conduct a physical examination, or collect forensic evidence (Keesbury \& Askew 2010).

\section{CONCLUSION}

This study revealed that sexual based violence resulted into health consequences $(76.8 \%)$ among survivors. Both males $(79 \%)$ and females $(76 \%)$ experienced health consequence almost equally. Males were 1.2 time more likely to develop health complications than female. SBV resulted into various types of health problems ranging from psychological trauma 143(51\%), physical injuries 75(27\%) to unwanted pregnancies 17(6\%). Psychological trauma $143(51 \%)$ was the most reported health problem. Males were more likely to suffer from psychological trauma, physical injuries and gastrointestinal injuries compared to females while females were more likely to suffer from STIs, gynaecological disorders, HIV, and unwanted pregnancies than males. Soft tissue injuries 49(17\%) mainly featured among people who suffered physical injuries as a result of SBV. Other injuries included limb injuries $13(5 \%)$, injuries on the anal region $9(3 \%)$ and pelvic pain $7(2 \%)$. Females were more at risk of suffering from soft tissue injuries while males from anal region injuries and limbs injuries. Majority of the respondents reported virginal fistula $24(9 \%)$ uncontrolled bleeding $18(6 \%)$, bruises in private parts $13(5 \%)$ and pelvic pain $3(1 \%)$. The only gastrointestinal disorder 20(7\%) reported by survivors was flatulence. Males were more likely to report flatulence compared to females. Adults 13(10\%) were more to report flatulence compared to children 7(4\%). Sexually transmitted infections 38(14\%) which were reported included HIV 35(12\%), syphilis 3(1\%), and urinary tract infection $1(0.4 \%)$. There was no significant difference between STIs cases in females and males; however females were at a higher risk of contracting STIs than males. Psychological consequences 143(51\%) were largely reported among the survivors of sexual based violence including fear 120(43\%), shame 91(32\%), depression $81(29 \%)$, anxiety $53(19 \%)$ and low-self esteem 46(16\%). Females were more likely than males to experience fear while males were more likely to experience shame and anxiety. Depression and low self-esteem were likely to be experienced equally by females and males.

\section{RECOMMENDATIONS AND POLICY IMPLICATION}

The study recommends that:

a) Life skills training is needed for both gender and mechanisms for coping with sexual violence need to be develop to minimise further suffering.

b) Formation of male and female action groups; mass/community sensitization on sexual violence including using vernacular FM radio stations and enhancing the capacity of ant-sexual violence advocates.

c) Education and communication strategy; Strengthening of the existing institutions handling sexual violence; Coordination of sexual violence related interventions by different stakeholders and strengthening networking.

d) Gender equity is essential in mitigating health consequences of sexual based violence; Legal aid services should be provided to those who are unable to meet them.

e) Environmental/collaborative/mutual approach or model can be used in dealing with SBV and health problems brought by it. It can also be called environmental approach/model or mutual approach/model. Collaborative approach should encompass the individual level, dealing with relationships, community level involvement, and societal level which should be supported by working legal institutions, committed 
political systems and active healthcare systems

\section{ACKNOWLEDGEMENT}

We appreciate the support given by Kenyatta University. Thanks to all respondents to the study and others who contributed to this script.

\section{REFERENCES}

Action for Development (ACFODE) (2009). Sexual and Gender Based Violence in Uganda:Experiences of Sexual Violence among Women and Girls in Pallisa and Kisoro Districts, Uganda.

Alcalá MJ, (2005). State of World Population 2005. The Promise of Equality: Gender Equity, Reproductive Health and the Millennium Development Goals. UNFPA. 2005. 65.

Africa Regional Sexual and Gender-Based Violence Network Consultation, (2008): Technical Exchange and Planning Meeting. Nairobi: Population Council.

Ajema, C. et al. 2009. "Standards required in maintaining the chain of evidence in the context of post-rape care services: Findings of a study conducted in Kenya." Nairobi: Liverpool VCT Care \& Treatment, the Kenyan Ministry of Health Division of Reproductive Health and the Population Council.

American Social Health Association (1998). Sexually Transmitted Diseases in America: How Many Cases and at What Cost? Menlo Park, CA: Kaiser Family Foundation.

Bhandari, N.,(2005). Working with men and boys: to end Violence against Girls, Boys, Women and other Men. Save the Children Sweden and UNIFEM, Kathmandu, Nepal.

Campbell, J., C. Garcia-Moreno, and P. Sharps, (2004). "Abuse during pregnancy in industrialized and developing countries," Violence against Women 10(7): 770-789.

Campbell, R. \& T. Self, (2004). "The Impact of Rape on Women's Sexual Health Risk Behaviours", Health Psychology, vol. 23, no. 1, pp. 67-74.

Ellsberg, M. and Heise L., (2005). Researching Violence Against Women: A Practical Guide for Researchers and Activists. Washington DC, United States: World Health Organization.

Ellis, J.C. et al., (2005). "Introduction of HIV post-exposure prophylaxis for sexually abused children in Malawi," Arch Dis Child 90:1297-1299

ESOG, (2009). Report on Dissemination Workshop in Addis Ababa (December 2009); Report on Dissemination Workshop in Nazareth and Hawassa. Population Council.

Fonck, K. et al., (2005). "Increased risk of women experiencing physical partner violence in Nairobi, Kenya." Population Council. Nairobi, Kenya. AIDS and Behavior 9(3): 335-339.

Garcia-Moreno, C., (2002). "Dilemmas and opportunities for an appropriate health-service response to violence against women," Lancet 359: 1509-1514.

General Assembly, (2006). In-Depth Study on All Forms of Violence against Women: Report of the Secretary General, 2006. A/61/122/Add.1. 6 July 2006.

Government of Kenya, Ministries of Public Health and Sanitation and Medical Services, (2010). National Guidelines on the Management of Sexual Violence in Kenya. Nairobi: Kenya.

Heise L., Ellsberg M. and Gottemoeller M., (2008) "Ending Violence Against Women." Population Reports, Series L, No. 11, cited by International Women's Health Coalition, "Triple Jeopardy: Female Adolescence, Sexual Violence and HIV/AIDS.” June 2008.

Interagency Gender Working Group (2006). Addressing Gender-Based Violence through USAID's Health Programs: A Guide for Health Sector Program Officers. Washington, DC.

Institute of Medicine. Committee on Prevention and Control of Sexually Transmitted Diseases, (1997). The Hidden Epidemic: Confronting Sexually Transmitted Diseases, eds. T. R. Eng and W. T. Butler. Washington, DC: National Academy Press.

Keesbury, Jill and Ian Askew. 2010. "Comprehensive responses to gender-based violence in low-resource settings: Lessons learned from implementation.” New York, NY: Population Council.

Keesbury Jill, Ian Askew, Monica Wanjiru, Grace Chiyaba, Kate Wilson and Felly Nkweto Simmonds, (2011).Comprehensive Responses to Sexual Violence in East and Southern Africa: Lessons Learned from Implementation. Lusaka: Population Council.

Keesbury, Jill, Mary Zama, and Sudha Shreeniwas, (2009). "The Copperbelt Model of Integrated Care for Survivors of Rape and Defilement: Testing the feasibility of police provision of emergency Contraceptive pills." Lusaka: Population Council.

Keesbury, J., Skibiak, J. \& M. Zama, (2006). "Reducing unwanted pregnancy among victims of sexual assault: New windows of opportunity for Emergency Contraception", Draft paper: Population Council: Lusaka, Zambia.

Kenya Ministry of Health/Division of Reproductive Health, 2004. National Guidelines on the Medical Management of Rape/Sexual Violence (1stedition). Nairobi, Kenya, Tonaz Agencies. 
Kilonzo, N \& M. Taegtmeyer, (2005). Comprehensive Post-Rape Care Services in Resource- Poor Settings: Lessons learnt from Kenya. Liverpool School of Tropical Medicine. Nairobi, Kenya, Liverpool VCT Kenya. Policy Briefings for Health Sector Reform : No. 6, September 2005.

Kilonzo, N., Keesbury, J., Maternowsko, C., (2009). Sexual violence: setting the research agenda for Kenya. Nairobi, Kenya.

Kishor, S. \& K. Johnson, (2004). Profiling Domestic Violence-A Multi-Country Study. Calverton, Maryland: ORCMacro.

Médecins Sans Frontières, (2009). Shattered lives: Immediate medical care vital for sexual violence victims. Médecins Sans Frontières, Brussels.

Mugawe, D. And Powell A. (2006). Born to high risks: Violence against girls in Africa. The African child policy forum.

Nakijoba Veronica, (2009). Access and utilization of health sector responses to sexual violence in conflict and post-conflict settings: the case of northern Uganda paper presented at the SVRI forum 2009, 6-9 July, Johannesburg, South Africa.

Onyango-Ouma W., Njoki Ndung'u, Baraza N., Birungi H., (2009). The making of the Kenya sexual offenses act, 2006: Behind the scenes. Nairobi: Kwani Trust.

Population Council, (2008). Sexual and gender based violence in Africa. Literature review Population council inc. Nairobi, Kenya.

Raifman,Sarah, Ian Askew, Sajeda Amin, Jill Keesbury, Saiqa Mullick, Judy Diers, Meiwita Budiharsana, ChiChi Undie, Mary Zama, Mantshi Menziwa, Sherry Hutchinson, and Naomi Rutenberg, (2011). "The prevention and management of HIV and sexual and gender-based. New York, NY: Population Council.

Sajeda A. and Althea D. A., (2011). Addressing sexual and gender-based violence (SGBV) against adolescent girls. New York, NY: Population Council.

Speight, C.G. et al., (2006). "Piloting post-exposure prophylaxis in Kenya raises specific concerns for the management of childhood rape." Transactions of the Royal Society of Tropical Medicine and Hygiene.

United Nations Fund for Women (UNIFEM), (2008). Baseline Survery on Sexual and Gender Based Violence in Rwanda. Applied Statistics of the National University of Rwanda, Rwanda.

Vetten, L. et al., (2008). Tracking Justice: The attrition of rape cases through the criminal justice system in Gauteng. Johannesburg: Tshwaranang Legal Advocacy Center, the South African Medical Research Council and the Centre for the Study of Violence and Reconciliation.

World Bank, (2005). Preventing and responding to gender-based violence in middle and low income countries: a global review and analysis. World Bank Policy Research Working Paper 3618, June 2005.

WHO, (2007). Post-Exposure Prophylaxis to prevent HIV infection. Joint WHO/ILO guidelines on Post-Exposure Prophylaxis (PEP) to prevent HIV infection. 20 Avenue Appia, 1211 Geneva, Switzerland.

WHO, (2005). WHO Multi-Country Study on Women's Health and Domestic Violence Against Women: Summary Report of Initial Results on Prevalence, Health Outcomes and Women's Responses. Geneva, Switzerland, WHO

Wong, T., Singh, A., Mann, J., Hansen, L. and McMahon, S., (2004) Gender Differences in Bacterial STIs in Canada. BioMed Central Ltd, Canada. 